\title{
Rerative Risk of Management Factors which Influence Infertility of Artificial Insemination in Bali Cattle in East Lombok
}

\author{
(RISIKO RELATIF FAKTOR-FAKTOR PEMELIHARAAN YANG \\ MEMENGARUHI INFERTILITAS HASIL INSEMINASI BUATAN \\ PADA SAPI BALI DI LOMBOK TIMUR)
}

Anwar Rosyidi, Adji Santoso Dradjat*, Lalu Ahmad Zainuri,
Lalu Wirapribadi, Tjok. Suwendra Binetra, Haryanto

Departement of Animal Production,

Faculty of animal Husbandry, University of Mataram,

Jl Majapahit No 62 Mataram, Nusa Tenggara Barat, Indonesia 83125

Telp (0370) 631166, *Email: adji.dradjat@yahoo.com

\begin{abstract}
The aim of this study was to evaluate odds ratio (OR) of management factors on infertility of artificial insemination results. Three traditional farmer groups were purposively choosed, based on percentage of calf born of AI program. Group I, with calves born of $61.22 \%$, Group II with calves born of $38,89 \%$, and group III with calves born of $30,0 \%$. The management factors evaluated were 1 . ownerships of cattle, 2 . raise cattle in separate pen with other, 3. cattle raised in pen dirty pen, 4. not enough feed given 5. body condition score. The data was obtained by dichotomy questioner and observation then evaluated using odds ratio $(\mathrm{OR})$, when OR more than 1 indicated the high risk of factor to infertility. The results of OR in Group I showed that ownership $(1,18)$, separated pen $(0,54)$, dirty pen $(2,11)$, less feed $(3,20)$ and body condition $(0,22)$. The results in Group II showed that ownership $(0,83)$, separated pen $(1,12)$, dirty pen $(0,14)$, less feed $(2,08)$ and body condition $(2,00)$. The results of odds ratios in Group III showed that ownership $(1,63)$, separated pen $(3,83)$, dirty pen $(0,88)$, less feed $(1,00)$ and body condition $(0,12)$. These data indicated that ownerships, dirty pen, less feed and body condition were factors which may confounding with other factors. However less OR of separate pen were, in Group I $(0,54)$, Group II $(1,12)$ and Group III $(3,83)$ consistently with number of calves produced. It can be concluded that separate pen was a factor which influence calves produced in using artificial insemination.
\end{abstract}

Key words: Odds ratio, management, insemination, infertility.

\begin{abstract}
ABSTRAK
Tujuan penelitian ini adalah melakukan evaluasi resiko relatif (odds ratio/ OR) factor-factor management yang berpengaruh pada infertilitas hasil artificial insemination. Tiga kelompok peternak dipilih secara purposive yaitu kelompok peternak I, dengan jumlah pedet $61.22 \%$, kelompok II, jumlah pedet 38,89\%, dan kelompok III dengan jumlah pedet 30,0\%. Faktor factor yang dievaluasi yaitu 1 . kepemilikan sapi, 2. kandang sapi yang terpisah pisah, 3. kandang sapi kotor, 4. pakan tidak mencukupi dan 5. kondisi badan sapi. Pengumpulan data dilakukan dengan survey menggunakan kuesioner yang bersifat dikotomi dan dievaluiasi menggunakan odds ratio (OR), bila OR lebih dari 1 maka factor tersebut beresiko terhadap infertilitas. Hasil odds ratios kelompok I menunjukkan bahwa kepemilikan $(\mathrm{OR}: 1,18)$, kandang terpisah $(0,54)$, kandang kotor $(2,11)$, kurang pakan $(3,20)$ dan kondisi badan $(0,22)$. Hasil pada kelompok II bahwa kepemilikan $(0,83)$, kandang terpisah $(1,12)$, kendang kotor $(0,14)$, kurang pakan $(2,08)$ dan kondisi badan $(2,00)$. Hasil penelitian pana kelompok III menunjukkan bahwa kepemilikan $(1,63)$, kandang terpisah $(3,83)$, kandang kotor $(0,88)$, kurang pakan $(1,00)$ dan kondisi badan $(0,12)$. Hasil penelitian menunjukkan bahwa kepemilikan, kandang kotor, kurang pakan dan kondisi badan kemungkinan berkaitan dengan faktor yang lain. Tetapi semakin rendah OR kandang terpisah, pada Group I $(0,54)$, Group II $(1,12)$ dan Group III $(3,83)$, semakin banyak jumlah anak sapi yang dihasilkan. Akhirnya dapat disimpulkan bahwa kandang terpisah antar sapi adalah faktor yang mempengaruhi hasil kebuntingan dan jumlah anak hasil inseminasi buatan.
\end{abstract}

Kata-kata kunci: Rasio relatif, manajemen, inseminasi, sapi Bali 


\section{INTRODUCTION}

Since 1960S, Nusa Tenggara Barat (NTB) province has been use as source of cattle and meat of Indonesia. Farmers in NTB raised cattle in traditionally way, as backyard farming, in small number, to save money and sold cattle when needed. However since two last decades farmer raise cattle in group, each farmer has their own pen in one place, to ease management and security.

As a source of cattle for inter-island and export there are regulation that the cattle exported should have body weight higher than $250 \mathrm{~kg}$. Consequently, by 2000s the rest of the cattle in NTB have smaller body weight. In order to increase cattle production, artificial insemination (AI) has been intensively performed to increase Bali cattle body weight. By using AI, farmers happy with bigger birth weight and faster growt rates of and farmers do not have to raise the bull anymore. Without bull there is problem in difficulty to detect cycling cows and detect oestrus for AI. Further problem raised, that under farmers condition percentage calves born by AI was relatively low, those were between $35 \%$ and $65 \%$ (NTB dalam angka 2017), the similar result was also found $50 \%$ of pregnancy in Sulawesi (Saili et al, 2017). On the contrary, by natural mating in South of Lombok pregnancy reach 92-93\% and calves borned 8586\% (Dahlanuddin et al, 2016). Hence by using $\mathrm{AI}$ increase reproductive wastage in cattle. Low pregnancy rates of AI results may influenced by several factors (Pane et al 2011; Da Costa et al, 2016) such as 1. Post thawed sperm quality. 2. Deposition of spermatozoa in the uterine by inseminator. 3. Estrous cows detected by farmers and 4. Management of cows by farmers for example ownership, feeding, hygiene of pen.

In NTB province, farmers rise cattle as backyard farming. The ownership of cattle was small between 1-3 cattle, consequently successful AI deppend on individual farmer management, such as ownership, pen management, feeding and body condition. Technical problems of AI can be solved technical improvement, while management problems should be solved by improvement of management. Hence, the aims of this study was evaluate odds ratio (Szumilas 2010; Martinez et al, 2017) of management factors which may influenced invertility cows using AI..

\section{RESEARCH METHODS}

Cattle being used in this study was Bali cattle (Bos indicus / Bos javanicus) in East Lombok of Indonesia. This cattle were rise by local farmers, in traditionally way by cutting grass around ricefields, rice straws following harvesting and also some time legume from their backyard, without any feed supplement. Feed given may less than $10 \%$ of body weight as recommended by (Ismaya et al, 2015) and may less than metabolism and physiology requirements. These groups of farmer were calf producer, however for breeding totally depend on AI. They do not have any bull or steers, since all the steers were send for fattening.

This study was performed by cross-sectional observation with outcomes namely prevalence ratio $(\mathrm{PR})$ or odds ratio $(\mathrm{OR})$ to measure an association with exposure (Szumilas 2010, Martinez et al, 2017).

Three goups of farmer were choosed purposively, the first group with higher number of calves (61.22\%) namely Tulung Danang with farmers member of 39 persons, raised 49 cows, number of calves were 30 heads and average of raising cattle was 1,25 cows. Second group with middle number of calves $(38,89 \%)$ was Sapeng with member of 15 persons, number of cows 36 heads, with calves AI results 14 heads and average of raising cattle 2,4 cows. Third group farmers was Sumber Rejeki with lowest number of calves (30,0\%), member of group 23 persons, number of cows 40 heads, with calves of AI results 12 head and average of raising cattle 2,04 cows.

Factors of component management which may influence AI results, such as 1. ownership, 2 . separat pen 3 . dirty pen 4 . feed given 5 . body condition was evaluated. Ownerships cattle is when the cattle are belonged and raised by farmer, on the contrary dicotomy with cattle which are not belong to farmers, but raised by farmer by agreement divident after selling. Separate pen is when there are distance 3 to 5 $\mathrm{m}$ or more from anothers pen, dicotomy with close between pen less than $3 \mathrm{~m}$. Dirty pen is when pen is not cleaned everyday and the feed forages may fell over and mixed with faeces may ate by cattle, this dicotomy with the pen is cleaned everyday. Poor feed or less feed is when feed given less than $10 \%$ of body weight, dicotomy with when feed given more than 10\% (Ismaya et 
al, 2015). Body condition score (BCS), score 1 when the cows is skiny, dicotomy with score 3 when the cows are fat.

The data was analised by measuring Odds Ratios ((Szumilas 2010, Martinez et al, 2017). Data evaluated were; $a=(n)$ exposed cases, $b=$ (n) exposed non-cases, $\mathrm{c}=$ (n) unexposed cases and $\mathrm{d}=$ (n) unexposed non-cases.

\section{Outcome status}

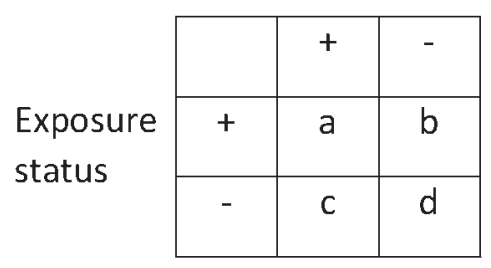

Odds ratios was calculated by $\mathrm{OR}=\frac{\mathrm{a} / \mathrm{c}}{\mathrm{b} / \mathrm{d}}=\frac{\mathrm{ad}}{\mathrm{bc}}$

The data analysed by comparing odds ratio (Szumilas 2010, Martinez et al, 2017) factors management which influenced to AI results between three categories of AI results. When odds ratio is $=1$, means that there is no outcome caused by factors to be exposed. If odds ratio less than $1(<1)$ there is slight effect exposed to the out come. When odds ratio higher than 1 or higher than 2 or more the out come affected to the expose (factors) is higher (Szumilas 2010; Martinez et al, 2017). As an example that exposure corpus luteum formation after AI may was found $(\mathrm{OR}=8.55)$ indicated high risk to produce infertility out come (Bragança and Zangirolamo 2018).

\section{RESULTS AND DISCUSSION}

The standard prosedure of AI have been proved to be able to fertilised ovum and produce pregnancy (Diskin, 2018), This standard has been used widely in NTB province, however, there are several components may contribute to produce pregnancy, such as good management adoptted by farmers, cows which have active ovaries, accurate oestrus detection, good inseminator skills and good quality semen used (Dradjat et al 2012). When one of those components missing, it would leads failure to fertilized. It was reported that poor farmer management may leads to infertility (Wodaje and Mekuria. 2016). Prevalence ratio or Odds ratio (OR) infertility cattle using artificial insemination under farmer management presented in Figure 1.

Figure 1, showed that in Group I with

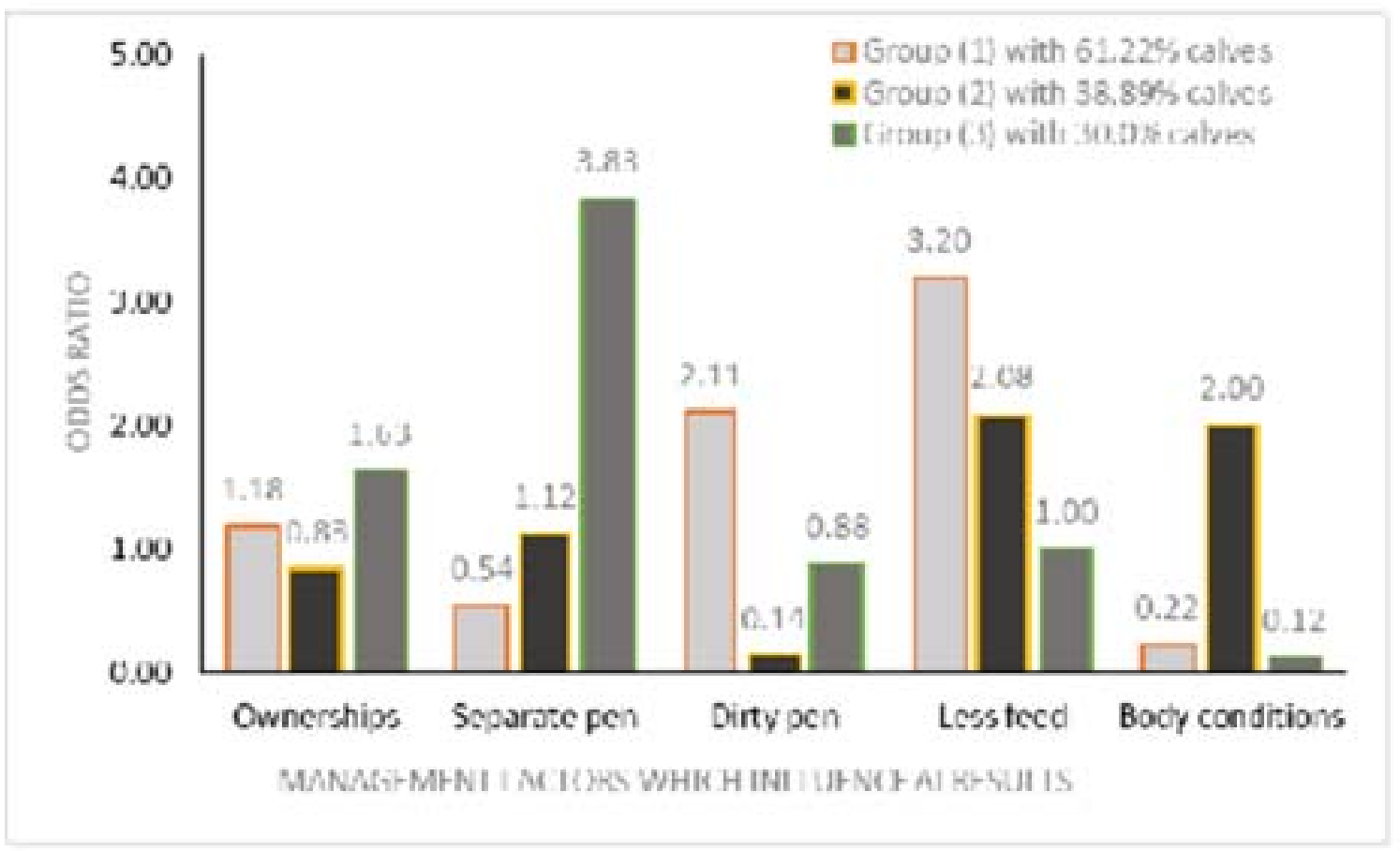

Figure 1. Odds ratio of factors which may influence the calving rate in tree farmer groups as acceptor of artificial insemination. 
$61.22 \%$ calves from mature cows showed of Less feed OR of 3.20, dirty pen OR 2.11 and ownership with OR 1.18. While Group II produced 38.89\% calves from the number of mature cows, this indicated that $61.11 \%$ cows may suffer of infertile. This group showed OR of not enough feed of 2.08, score body condition with OR of 2.00 and separate pen showed OR of 1.12. Figure 1, showed that Group III only produced 30,0\% calves, indicated that infertile may reach $70 \%$ mature cows. The results showed that the cows were raised in separate pen with distance between 3 to 5 meter or more indicated higher risk of infertility with OR of 3,83. Ownerships OR was 1.62 and less feed was 1.00. The OR which less than 1.00 was less risk to fertility or number of calves produced was considered as less association with exposure (Szumilas 2010; Martinez et al, 2017).

Ownerships factor. The result showed that OR ownership factor was found fluctuated with high, middle and low results $\mathrm{AI}$ and it seems that ownership factors may confounding with other factors (Figure 1). Ownership may risk to $\mathrm{AI}$ results is when farmers look after and raised some body else cows, the farmer work harder than that of cattle belong to themselves. When farmer raise their own cattle, the do not look after their own better than cattle belong to some one else. Traditional farmer rear cattle for saving the money, they may sell their cattle when they need money (Zainuri et al 2002). Most of farmers have to work hard by cut and carry grass, and only able to raise two or three cows, hence may not be able to spent more time such as to do estrous detection (Zainuri et al 2002). In addition, when farmer busy with plowing, planting and harvesting they less care to their cows.

Separate pen factor. The results of separate pen showed that when the OR is low the risk of fertility or number of calves produced, was high. (Figure 1) This indicate that separate pen was a single factors which associated with outcome of fertility and number calves produce using AI. Raise cattle in separate pen and unseparate was related to the need of cows interaction of to showed oestrus behaviour. When the cows stayed in separat pen, thighten with rope on the nose to the pole would not have a chance to make interaction to other cattle and consequently the cows may showed silent oestrus (Haque et al, 2015). As the cattle is a herd animal, interaction between cattle is important, especially to induces sexual behaviour during heat (Haque et al, 2015).
This can be explain that the farmer only have a small number of cow, without any bull. It seems that without interaction between them, the cows may not stimulated to showed and exposed oestrus behaviour (Dradjat et al, 2014). It is indicated that interaction with other cows or steers may trigger oestrus behavior to make easy to be detected by farmers with specific sign of oestrus those called standing oestrus, where the cow stood still when other cows or steer stand on their back is the sign of oestrus (Haque et al, 2015).

Dirty pen factor. OR of dirty pen was found fluctuated between high, medium and low number of calves (Figure 1). It can be explain that exposure of dirty pen may counfounding with other factors to influence to the results of AI. Dirty pen effect to fertility can be explained that if grass and other feed fell and drop to the dirty floor and mixed with faeses, and eaten by cows, it may lead to parasite and worm and other infection. Dirty pen also become reservoir of worm larva, other parasites and also source of infestation and infection of parasites and bacterials. Sub acute and chronic diseases able to influenced oestrus cycle and oestrus behaviour and reduce fertility with AI. Previous study (Yusuf et al, 2010) showed that reproductive diseases such endometritis was the risk factor for sub-fertility with odds ratio $(\mathrm{OR})=3.76$. Another study (Wodaje and Mekuria. 2016) showed that poor dirty floor may related to infertility.

Poor feeding factor. Odd ratio of less feed exposure, with higher OR showed high fertility and less OR showed higher outcome. (Figure 1).It seems that feeding factor may confounding with other factor to produce infertility using AI. When less feed was given or less than $10 \%$ of body weight may risked to the success of AI. It was reported that cows raised with good feed produced $63.5 \%$ pregnancy, while given less quality feed product pregnancy of $38.5 \%$ (Haque et al, 2015). Other report showed tha poor nutrition may related to infertility (Wodaje and Mekuria. 2016). It was reported that less feed may disrupt hypothalamus production and release of $\mathrm{Gn}-\mathrm{RH}$, then the respons of pituitary may also release less FSH and LH. Consequently follicles on the ovary produce less estrogen, which may resulted in short time of heat and less behaviour. It means that optimum time of insemination also in a short time (Baruselli et al, 2017) may reduce pregnancy rates of insemination. Further study (Yusuf et al, 2010), showed that delayed first 
ovulation $(\mathrm{OR}=6.02)$, and delayed corpus luteum formation after $\mathrm{AI}(\mathrm{OR}=8.55)$ were the risk factors to produce infertility and It was also reported (Bragança and Zangirolamo 2018) that poor nutrition practices may lead infertility. However, in the present study, the number of calves do not have association exposure of feeding. This case may unexplanable except exposere feeding may confounding with other factors which influence fertility using AI.

Body condition factor. Odd ratio of body condition factor was found not related to fertility or number of calves produced and this factor may confounding with other factors and without consistent influenced to fertility in AI program (Figure 1). Previous research showed that AI performed in cattle with body condition score 3 and 1,5 to 2 resulted in $58 \%$ and $35,0 \%$ pregnancy rate respectivelly (Haque et al, 2015). Kim and Jeong, (2019) reported that cows with BCS <3.0 had a lower probability of conceiving at first insemination (odds ratio $[\mathrm{OR}]=0.64, \mathrm{p}<0.05$ ) than those cows with BCS e"3.0. It indicated that enough feed resulted in higher level of blood carbohydrate, fat and protein and this may leads to good body condition. Consequently, the cows can sintesize reproductive hormones as hypothalamus and hypophysis hormones are syntesized from protein, while steroids hormone synthesise from fats, especially from sterol chains. When feed requirement can be achieved, reproductive hormones can be sinthesized (Baruselli et al, 2017), the cows may have normal cycles, good behaviour and signs of oestrus which easy to detect and finally produce pregnancy by AI.

\section{CONCLUSION}

From the overall study, It can be concluded that OR separate pen was related to the fertility or number of calves. Low OR of separate pen showed high mumber of calves, while high OR showed lower number of calves, while the other factors may confounding with others. It can be said that separate pen is a factor which influence fertility by using artificial insemination under rural condition in East Lombok Island of Indonesia.

\section{SUGGESTION}

It can be suggested that OR can be used to list priority for improvement management to increase fertility by using artificial insemination. Further research need to be performed to evaluate nutrition exposure factors may confounding with other factors which may influence infertility such as reproductive states of cows, inseminators skill and semen quality.

\section{ACKNOWLEDGEMENT}

This research was funded by (PNBP) Mataram University 2019, with letter of agreement No: 2837R/UN18.L1/PP/2019, 2 Mei 2019.

\section{REFERENCES}

Baruselli PS, Ferreira RM, Colli MHA, Elliff FM, Sa Filho MF, Vieira L and de Freitas B.G. 2017. Timed artificial insemination: current challenges and recent advances in reproductive efficiency in beef and dairy herds in Brazil. Proceedings of the 31st Annual Meeting of Brazilian Embryo Technology Society (SBTE). Cabo de Santo Agostinho, PE, Brazil, August 17 th to 19th, 2017.

Bragança LG. and Zangirolamo AF. 2018. Strategies for increasing fertility in high productivity dairy herds. Proceedings of the 32nd Annual Meeting of the Brazilian Embryo Technology Society (SBTE); Florianopólis, SC, Brazil, August 16th to 18 th, 2018.

Da Costa N, Susilawati T, Isnaini N and Ihsan M.N. 2016. The difference of artificial insemination successful rate of onggole filial cattle using cold semen with different storage time with tris aminomethane egg yolk dilution agent. IOSR Journal of Pharmacy. 6: 13-19.

Dahlanuddin, Zaenuri LA, Sutaryono YA, Hermansyah P, Puspadi K, Mc Donald C, Williams LJ, Corfield JP and van Wensveen M. 2016. Scaling out integrated village management systems to improve Bali cattle productivity under small scale production systems in Lombok, Indonesia. Livest. Rur. Res. Dev. 2016.

Diskin M.G. 2018. Review: Semen handling, time of insemination and insemination technique in cattle. Vol 12, Supplement 
(Theory to Practice) - International Bull Fertility Conference 27-30 May 2018, Westport, Ireland) June 2018, pp. s75-s84.

Dradjat AS, Rodiah, Arman C and Yuliany E. 2014. Identifikasi masalah untuk meningkatkan pelayanan pelaksanaan inseminasi buatan pada sapi bali pada peternakan rakyat di kabupaten lombok barat. Laporan penelitian Fak Peternakan Universitas Mataram 2014.

Haque MN, Gofur MR, Asaduzzaman KM and Bhuiyan MMU, 2015. Factors limiting the pregnancy rates in artificially inseminated cows in Bangladesh. International Journal of Dairy Science, 10: 278-287.

Ismaya, Erwanto Y, Sasongko H, Ariyadi B, Widi TSM, Umami N,Noviandi CT,Anim M, Wijonarko A and Hardaningsih I. 2015. Integrated faring system: dalam pengentasan Kawasan rawan pangan. Pusat Kajian Pembangunan Peternakan Nasional, Fakultas Peternakan Universitas Gajah Mada.

Kim I H and Jeong J K. 2019. Risk factors limiting first service conception rate in dairy cows and their economic impact. AsianAustralas J Anim Sci. 2019 Apr; 32(4): 519 526. Published online 2018 Sep 13. doi: 10.5713/ajas.18.0296.

Martinez BAF, Leotti VB, Silva GS, Nunes LN, Machado G and Corbellini LG (2017) Odds Ratio or Prevalence Ratio? An overview of reported statistical methods and appropriateness of interpretations in crosssectional studies with dichotomous outcomes in veterinary medicine. Front. Vet. Sci. 4:193.

Nusa Tenggara Barat (NTB) Dalam Angka 2017. https://ntb.bps.go.id/publication/2017/08/11/ 1103bba2fddbb55c8c92d896/pr.
Pane J, Salesa NS, Nevesa KAL, Souzaa AH, Crepaldia GA, Salaa RV, Fosadob M, Campos Filhob EP, de Fariac M, SáFilhoa MF, Barusellia PS, 2011. Timing of insemination and fertility in dairy and beef cattle receiving timed artificial insemination using sex-sorted sperm. Theriogenology. Volume 76, Issue 3, August 2011, Pages 427435.

Saili T, Baa L.O, Napirah A, Syamsuddin, Sura IW and Lopulalan F. 2017. Pregnancy rate of Bali cows following artificial insemination using chilled sexed sperm under intensive management in tropical area. The 7th International Seminar on Tropical Animal Production, September 12-14, Yogyakarta , Indonesia 2017.

Szumilas M. 2010. Information management for the busy practitioner"Explaining Odds Ratios. J Can Acad Child Adolesc Psychiatry, 19:3, August 2010

Wodaje HB and Mekuria TA. 2016 Risk Factors of Repeat Breeding in Dairy Cattle. Advances in Biological Research. 10 (4): 213221, 2016. DOI: 10.5829/idosi.abr.2016. 10.4.104142.

Yusuf M, Nakao T, Long ST and Gautam G. 2010. Analysis of some factors affecting fertility levels in a high-producing dairy herd in south-western Japan. Anim Sci J. 2010 Aug 1;81(4):467-74. doi: 10.1111/j.17400929.2010.00764.x.

Zainuri L.A., Dahlanuddin., Muzani, M., Panjaitan, T., Pany, H. (2002). Persepsi Peternak Nusa Tenggara Barat Terhadap Sapi Bali. Laporan Hasil Penelitian. Kerjasama ACIAR, BPTP dan Fakultas Peternakan Unram. 